\title{
Early detection and preventive control of Rhynchophorus ferrugineus (Coleoptera Curculionidae): a quarantine pest in Brazil
}

\author{
V.A. Dalbon ${ }^{1}$, J.P.M. Acevedo ${ }^{2}$, A.E.G. Santana ${ }^{3}$, H.F. Goulart ${ }^{3}$, I. Laterza ${ }^{4}$, \\ A. Riffel ${ }^{5}$, A. Negrisoli $\mathbf{J r}^{5}$, B. Lohr ${ }^{2}$ and F. Porcelli ${ }^{4}$
}

(1) Doctoral Student in Biotechnology Natural Resources Renorbio, University Federal of Alagoas, Brazil, email: viviane.dalbon@iqb.ufal.br; (2) Researcher in Colombian Corporation of Agricultural Research, Agrosavia, Colombia; (3) Associate Professors of University Federal de Alagoas, Brazil; (4) Doctoral student and Associate Professor of University of Bari Aldo Moro, DiSSPA, Via Amendola, 165/A 70126 Bari - Italy;

(5) Researcher in Brazilian Corporation of Agricultural Research - Embrapa Tabuleiros Costeiros, Sergipe, Brazil

\begin{abstract}
Dalbon, V.A., J.P.M. Acevedo, A.E.G. Santana, H.F. Goulart, I. Laterza, A. Riffel, A. Negrisoli Jr, B. Lohr and F. Porcelli. 2019. Early detection and preventive control of Rhynchophorus ferrugineus (Coleoptera Curculionidae): a quarantine pest in Brazil. Arab Journal of Plant Protection, 37(2): 130-135.

Red palm weevil (RPW) Rhynchophorus ferrugineus was described as pest from tropical Asia, Mediterranean Europe, North Africa and America (California USA, 2009 and Curacao and Aruba, 2011). There is a risk for RPW invasion in South and Central America, where the weevil could infest economic palms as coconut and Guinean oil palm. The possible invasion represents a severe risk to Brazilian agriculture, and now RPW is an A1 quarantine pest with pending alert. Having available a preventive strategy of monitoring and control before the pest enters the Country would mitigate the threat for the agriculture. Because of this we are developing in Brazil a semiochemical and biological control based strategies for RPW early detection and control. We set tests with Ferrugineol in olfactometer and lured traps in field to evaluate that semiochemical use to evaluate luring of the South American palm weevil (SAPW) Rhynchoporus palmarum as a model pest. Moreover, biological control agents such as entomopathogenic fungi and nematodes are now available for virulence bioassays in Brazil. Field tests will be conducted with a combination of semiochemical and biological agents to determine the level of control with R. palmarum. Subsequently, tests with RPW outside Brazil will be carried out. We expect to find promising combination of mass trapping and biocontrol agent to propose an effective action for the RPW management and the contemporary evaluation of its control efficacy. The study will suggest a new component to develop sustainable control strategies by the joining of intercontinental experiences and approaches.

Keywords: Palmaceae, pest alert, insect attack, microbial control, ethological control, America.
\end{abstract}

\section{Introduction}

Red palm weevil, Rhynchophorus ferrugineus (Olivier, 1970) (Coleoptera: Curculionidae), hereafter RPW, is endemic in large areas of Asia, but has invaded the Middle East and Europe in the 1980's, and more recently North America and the Caribbean. The adult beetles are relatively large, ranging from two to four centimeters long, and usually exhibit a rusty red color. However, many color variants exist, which often lead to mis-identifications (Rugman-Jones et al. 2013). The larvae excavate galleries up to a meter long and propagate microorganisms (Scrascia, et al., 2016) in the stipe of a palm trees, thereby weakening and eventually killing the host plant. As a result, the weevil is considered a major pest in palm plantations in the world, including the coconut palm, date palm and oil palm (Rochat el al., 2017).

Since 1972 RPW was detected and initiated dispersion in tropical Asia (Indonesia). Between 1980 to 1994 its range expanded to India, the Persian Gulf, and Israel until arriving in North Africa and Mediterranean Europe (Italy, Portugal and Spain) (Rochat el al., 2017). In 2009 RPW was detected in California and in December 2008 in the Caribbean island of Curacao (Roda et al., 2011) and in 2009 in the Caribbean island of Aruba near the Venezuelan coast (Löhr, 2015).

The arrival of this pest to Curaçao is suspected to be due to the importation of mature date palms from Egypt for landscaping in hotel and residential developments (Roda et al., 2011). Shipments of palms from Curacao to Aruba, and the lack of local phytosanitary policies and regulations, have resulted in the most recent establishment of RPW on Aruba. Fiaboe and Roda, (2012) presented prediction maps, based on the adaptability characteristics of the pest, with pest establishment likely in all tropical and subtropical environments of South and Central America and Central Africa.

The first sign of infestation by the pest is yellowing and wilting of palm leaves. The crown wilts first, and lower leaves will follow, due to damage to vascular tissue. Major symptoms such as crown loss or leaf wilt are usually only visible long after the palm has become infested. By the time these external symptoms are observed, the damage is usually sufficient to kill the tree, and the infestation may have been present for six months or longer. In high-density infestations, sounds of the larvae burrowing and chewing can be heard by placing one's ear to the trunk of the palm. Recent research has been conducted using electronic listening devices or dogs trained to recognize the scent of weevils or palm decay to detect infestations at low densities earlier in the process (Rochat el al., 2017).

The prevention of entry of high risk organisms to potentially vulnerable countries is necessary. Such prevention can be achieved through offshore mitigation

http://dx.doi.org/10.22268/AJPP-037.2.130135

(C) 2019 Arab Society for Plant Protection الجمعية العربية لوقاية النبات 
strategies ranging from diagnosis of the presence/absence of a pest threat in adjacent countries and/or territories to eradication. The principal risk at present, is the invasion of South America by RPW, in particular for the main producer countries of commercial palm species like Brazil and Colombia. Brazil has 280,000 hectares cultivated with coconut and 210,000 hectares with oil palms (ABRAPALMA, 2017), while Colombia has 30,000 hectares cultivated with coconut and 470,000 hectares with oil palms (Dane, 2015.; Abrapalma, 2017) which would be endangered by the eventual invasion of $R$. ferrugineus.

In America, another palm weevil exist, with similar behavior and biology, and can be a model for RPW management, called South American palm weevil SPW, Rhynchophorus palmarum (Coleoptera: Curculionidae). This weevil is common in virgin forests and in agroecosystems infesting all commercially important palm species mainly of Cocos nucifera L. (Arecales: Arecaceae), Elaeis guineensis Jaqc. (Arecales: Arecaceae) (Sánchez and Cerda, 1993), in addition to ornamental palm species. The larvae of $R$. palmarum feed exclusively on live vegetative tissue. Studies on the population dynamics of this species in Brazil showed that the maximum adult population peaks during the dry season (Schuiling and Van Dinther, 1981). Bain and Fedon (1951) determined that $R$. palmarum is the most important vector of the phytonematode Bursaphelenchus cocophilus (Cobb) (Aphlenchida: Parasitaphelenchidae) which is the causal agent red ring disease of coconut and oil palm disease. The nematode is an obligate parasite distributed in all tissues of the plant. Redring disease has reached epiphytotic levels in the past (Griffith, 1968). The external symptoms on infested palms are a progressive yellowing of the foliar area, destruction of the emerging leaf and flowers necrosis. Leaves start to dry in ascending order in the crown; the apical leaf bends and eventually drops. However, these external symptoms are not sufficient for clear diagnosis. Internally, the galleries and damage to leaf-stems produced by the larvae are easily detected in heavily infested plants. Large economic impact of SPW in South and Central America has been reported in Brazil, Colombia, Venezuela and Costa Rica. The larvae of SPW feed on the tender tissue in the crown of the palm, often destroying the apical growth area and eventually causing death of the palm. Economic damage depends on the palm species and on the number of infesting larvae (Dalbon et al., 2018).

Esser and Meredith (1987) estimated that several million USD are lost annually due to the association of redring disease and SPW. They estimated that 800 ha of coconut plantations were abandoned due to this disease in Grenada, with $22 \%$ of the coconut palms were infested with red-ring disease. A similar situation seems to be common in other countries in America. More recently in Colombia, in the years 2014-2016, the damage of SPW in the pacific coast affected 8,000 hectares of coconut palms and 470,000 ha of oil palm. In Brazil $R$. palmarum affected coconut and oil palms an area of at least 250,000 hectares.

Control strategies have to take into account that SPW is a pest in its own right and a vector of $B$. cocophilus. The control of red-ring disease is currently conducted by controlling the insect vector but there is no efficient control method of the nematode. Chemical control of the insect, although often attempted, is not successful (Hagley, 1963). Cultural control consisting in the eradication and burning of affected trees reduce infestation. Chemical killing and drying of infected plants also reduce infestation (Griffith, 1987), as larvae need living plant tissue in order to survive. The most widely used control methods are based on the capture of adults with traps baited with rotting plant materials, such as palm tissue, pineapple and sugar cane. Recent traps, use synthetic pheromone based to capture the insects. Moura et al. (1989) and Rochat et al. (1991a) showed that males produce an aggregation pheromone while feeding, attracting males and females equally. Rochat et al. (1991b) identified the pheromone as 2(E)-6-methyl-2-hepten-4-ol, naming it rhynchophorol.

SPW was added in 2005 to the EPPO A1 action list, and endangered EPPO member countries are thus requested to regulate it as a quarantine pest. Rhynchophorus palmarum presents a significant phytosanitary risk to date palms in Central America, North Africa, and to ornamental palms planted throughout the Mediterranean basin. At present, an integrated pest management (IPM) system for SPW in South America does not exist. New tools, including biological control and further ecological control methods are under development at Universidade Federal of Alagoas in Brazil and Embrapa Tabuleiros Costeiros.

\section{Potential strategies of early detection and control of red palm weevil in Brazil}

The potential control tools for R. ferrugineus before its arrival in South America must lie on a preventive and protective approach (Porcelli and Cornara, 2013 and Porcelli et al., 2012), given the previous failure experienced in purely mass-trapping based control.

In the specific case of $R$. ferrugineus, the rapid detection and availability of an array of control tools would avoid great economic losses for the permanent crops of coconut and oil palm. To develop biological and ethological control strategies for the control of palm weevils (Rhynchophorus palmarum and R. ferrugineus) is necessary to evaluate native and exotic biological agents and semiochemicals, to determine control efficacy, initially in SPW like pest control, to determine the more effective biocontrol for the future containment of RPW in Brazil and South America (Dalbon et al., 2018).

\section{Exploitable foreground}

Some examples of biological agents for evaluation, selection and use in IPM for $R$. palmarum and potentially $R$. ferrugineus, in case of invasion in South America, will be mentioned in this paper.

Microbial Agents: Pathogens like fungi (Beauveria spp., Metarrhizium spp.) and nematodes (Steinernema spp., Heterorhabditis spp.,) have been applied to suppress pest populations of SAPW and RPW. A wide range of microorganisms suppress pests by producing toxins, causing disease, preventing establishment of other microorganisms 
or possibly by other mechanisms. Such microorganisms include bacterias, viruses, fungi and nematodes.

Entomopathogenic fungi, have been applied in Brazil since the 1990s. Beauveria bassiana strains have been isolated from dead weevils (Santana and Lima, 1992). Since then, EMBRAPA has conducted laboratory and field bioassays in order to develop the pathogenic B. bassiana strain CPATC 032 as an effective biological control of $R$. palmarum. The inoculation of adults in pheromone traps (capture - release) can be used to disseminate fungal conidia to other individuals due to the aggregation behavior. Additionally, fungal suspentions can be sprayed on plants (Ferreira and Lima, 1996). Inoculation of fungal conidia of CPATC 032 in combinations with pheromone traps have resulted in reduction of insect population level up to $72.2 \%$ (Ferreira and LIma, 1996).

Entomopathogenic nematodes (Rhabditida: Steinenrnematidae and Heterorhabditidae) have been described as an additional biological agent for control of adults of SAPW. The main research had started in 2014 through cooperation between Embrapa Tabuleiros Costeiros and Federal University of Alagoas. Actually in Embrapa in alliance with Colombian Corporation of Agricultural Research Center (AGROSAVIA) created a complete entomopathogenic nematodes bank with species and native strains like Heterorhabditis amazonensis JPM4.; Steinernema carpocapsae Santa Rosa strain.; Heterorhabditis sp. P5.; Steinernema feltiae; Steinernema brasiliense; Heterorhabditis amazonensis RS03. Heterorhabditis amazonensis RS05., Heterorhabditis bacteriophora, Heterorhabditis amazonensis MSC01. (Acevedo et al.; 2018). For RPW, Heterorhabditis bacteriophora and Steinernema carpocapsae applied in field conditions with chitosan formulation, cause over $80 \%$ mortality. Laboratory tests in Brazil indicated that nematodeinduced mortality was significantly greater than that produced by the following native nematodes: $S$. carpocapsae Santa Rosa strain, $H$. amazonensis strain JPM4, $S$. brasiliense, Heterorhabditis sp P5, with mortalities in larvaes and adults between 80 to $100 \%$. The preliminary results suggested that the use of selected EPN species in field experiments are needed to evaluate their potential under environmental conditions for the control of SAPW and EPN and could use in RPW trials as a potential biological control agent (Acevedo et al., 2018).

\section{Tachinid parasitoids}

The natural occurrence of the tachinid parasitoids Billaea rhynchophorae and Billaea menezesi on larvae of the palm weevil Rhynchophorus palmarum (L.) has been documented in plantations of piassava palm (Attalea funifera Mart.) and African oil palm (Elaeis guineensis Jacquin), in Ilheus, southeastern Bahia, Brazil (Moura et al., 1993, 2006). The average parasitism ranged from $40 \%$ up to $72 \%$. The bioecology of these parasitoids is currently subject of research by a consortium led by AGROSAVIA with contributions of CEPLAC and EMBRAPA with the aim to introduce the parasitoids to Colombia. The potential of these parasitoids has been completely overlooked in attempts to control $R$. ferrugineus in the Mediterranean and the Gulf region.
An artificial method of massive production of this parasitoid is still unavailable. The development of a method of mass production for an inundative liberation would be an additional management practice for $R$. palmarum and $R$. ferrugineus IPM. Mass rearing of tachinid parasitoids on artificial diet has been developed for other tachinid species (Dindo et al., 2006; 2007) and an effort will be made to adapt this technology to Billaea spp.

\section{Pest behavior-modifying chemicals}

Semiochemicals are important tools for pest management, either for luring pests to traps, or for disrupting mate or host location. Pheromone-based trapping systems have been used as an efficient method in RPW IPM. Early detection and monitoring help to plan further actions, whereas mass trapping reduces population and infestation levels. Hallett $e t$ al. (1999) reported that males of RPW were found to produce the aggregation pheromone 4-methyl-5-nonanol (ferrugineol), which attracts both males and females. The use of pheromone-based trapping and an effective management of RPW have been widely demonstrated in the Middle East (Hallett et al., 1999; Soroker et al., 2005; Faleiro et al., 2011). The best semiochemical-based trapping system for RPW in Mediterranean basin is composed of three main components: trap, ferrugineol (the aggregation pheromone) and natural compounds emitted by the host plant (kairomone).

The synthetic kairomone (ethyl acetate/ethanol) was reported to improve the attractant level of ferrugineol. The synthetic blend was as effective as the natural kairomones as coattractants (plant material + molasses) (Vacas et al., 2017). Though $R$. ferrugineus and $R$. palmarum are closely related, they do not share the same host plant range. The analysis of volatiles from hosts and non-host plants (green leaves, male inflorescence, healthy meristem and decaying tissues) may allow the identification of new kairomones or repellents and masking odours.

The biological control by using entomopathogenic microorganisms is another important technique to be included in any IPM program. The fungi Beauveria bassiana and Metharizium anisopliae causing high $R$. ferrugineus mortality rates, ranging from 60 to $87 \%$, have been described (Gindin et al., 2006; Dembilio et al., 2010; Lo Verde et al., 2015). Semiochemical-based control methods including mass trapping and attract and infect procedures using entomopathogenic fungi to control RPW have also been reported. Laboratory and field trials have shown that these strains have enormous potential for controlling this palm pest.

\section{Perspectives for integrated pest management for all strategies of control against $R$. palmarum and R.ferrugineus in the field in Brazil}

The major components of the IPM strategy for $R$. ferrugineus and $R$. palmarum are surveillance, trapping the weevil using pheromones lures, detecting infestation by examination of palms, implementing quarantine measures, training and education (Abraham et al., 1998). In Saudi Arabia, Vidyasagar et al. (2000) successfully developed an IPM 
programme which, in addition to mass pheromone trapping, included a survey of all cultivated gardens and systematic checking of all palms for infestation. A more detailed review of control strategies and IPM for the weevil were also published (Ramachandran, 1998; Murphy and Brisco, 1999.; Faleiro et al., 2011).

The entry of RPW in Brazil without a preventive strategy of monitoring, control and integrated management would be a critical threat for agriculture. In order to develop local early detection and control of RPW in Brazil, we have developed a semiochemical-based and biological control strategy. We set Ferrugineol-lured traps to try attraction tests targeting the South American Palm Weevil (SAPW) Rhynchoporus palmarum (Coleoptera Curculionidae) as a model pest. Moreover, kairomones from $C$. nucifera and $E$. guineensis, Ferrugineol in combination with biological control agents in further studies of chemical ecology will contribute to RPW control. Field tests will be conducted by a combination of semiochemical and biological agents to determine the level of control obtained with $R$. palmarum. Subsequently, tests with RPM outside Brazil will be carried out. As a result, we expect to evaluate ferrugineol and other effective volatile compounds for monitoring $R$. ferrugineus after the occurrence of the pest (early detection) in Brazil and contribute with others strategies in IPM of this pest. We expect to join efforts with different institutions in Brazil, South America and International Research Centers and Universities to contribute towards improvement of RPW management.

\begin{tabular}{|c|}
\hline 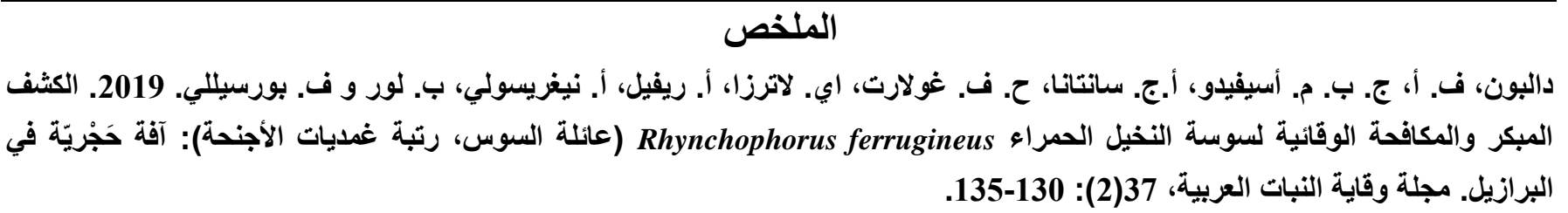 \\
\hline 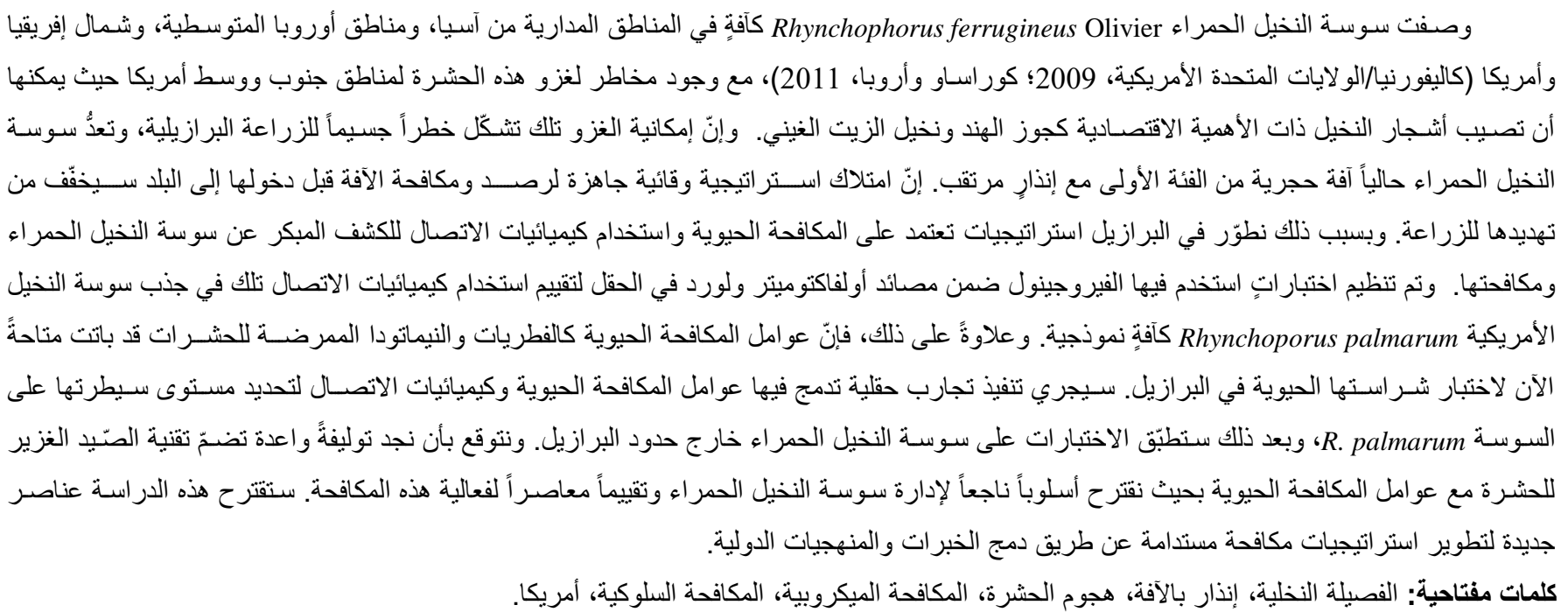 \\
\hline
\end{tabular}

\section{References}

Abraham, V.A., M.A. Al Shuaibi, J.R. Faleiro, R.A. Abozuhairah and P.S.P.V. Vidyasagar. 1998. An integrated management approach for red palm weevil, Rhynchophorus ferrugineus Oliv. - A key pest of date palm in the Middle East. Sultan Qaboos University Journal of Agricultural and Marine Sciences, 3:77-83 https://doi.org/10.24200/jams.vol3iss 1pp77-83

Abrapalma. 2017. http://www.abrapalma.org/pt/a-palmano-brasil-e-no-mundo/

Bain, F. and C. Fedon. 1951. Investigations on red ring of coconut. Agronomia Tropical, 1: 103-130.

Acevedo, J.P.M., A.S. Negrisoli Jr., B.L. Lhor, V.A.S. Junior, P.S. Santos, E.T. Da Silva and R.R. Ferreira Cuesta. 2018. Pathogenicity of entomopathogenic nematodes against immature stages of Rhynchophorus palmarum as potential tool for biolical control of Rhynchophorus ferrugineus for Tropinal America. In:
International Meeting Innovative and Sustainable Approches for the Control of Red Pal Weevil. CIHEAM Bari, Italy, 23 -25 October, 2018. P: 32

Dalbon, V.A., A.E.G. Santana, J.P.M. Acevedo, A. Riffel, H.F. Goulart and F. Porcelli. 2018. Early detection and warning by ferrugineol combined with other volatile compounds for the biocontrol of Rhynchophorus ferrugineus (Coleoptera Curculionidae): a quarantine pest in Brazil. Book of ABSTRACTS in the International meeting Innovative and sustainable approches to control the Red Palm Weevil (RPW). CIHEAM Bari, 23-25 October 2018. P: 43

Dane. 2015. Boletín técnico Encuesta Nacional Agropecuaria -ENA-DANE-COLOMBIA https://www.dane.gov.co/files/investigaciones/agrope cuario/enda/ena/2015/boletin_ena_2015.pdf 
Dembilio, Ó., M.E. Quesada, S.C. Álvarez and J.A. Jacas. 2010. Potential of an indigenous strain of the entomopathogenic fungus Beauveria bassiana as a biological control agent against the red palm weevil, Rhynchophorus ferrugineus. Journal of Invertebrate Pathology, 104: 214-221 https://doi.org/10.1016/j.jip.2010.04.006

Dindo, M.L., S. Grenier, L. Sighinolfi and P. Baronio. 2006. Biological and biochemical differences between in vitro and in vivo-reared Exorista larvarum. Entomologia Experimentalis et Applicata 120: 167174.

https://doi.org/10.1111/j.1570-7458.2006.00438.x

Dindo, M.L., E. Marchetti and P. Baronio. 2007. In vitro rearing of the parasitoid Exorista larvarum (Diptera: Tachinidae) from eggs laid out of host. Journal of Economic Entomology 100: 26-30. https://doi.org/10.1093/jee/100.1.26

Esser, R. and J. Meredith. 1987. Red ring nematode. Nematology Circular of the Florida Department of Agriculture no. 141, Gainesville (US).

Faleiro, J.R., M.A. El-Saad and A.H. Al-Abbad. 2011. Pheromone trap density to mass trap Rhynchophorus ferrugineus (Coleoptera: Curculionidae/ Rhynchophoridae/ Curculionidae) in date plantations of Saudi Arabia. International Journal of Tropical Insect Science, 31:75-77. https://doi.org/10.1017/s1742758411000099

Ferreira, J.M.S. and M. Lima. 1996. Transmissão de Beauveria bassiana na população de Rhynchophorus palmarum através do contato entre indivíduos contaminados e não Contaminados. In: Simpósio De Controle Biológico, 5, 1996, Foz do Iguaçu, PR. Resumos... Foz do Iguaçu: SEB, 1996. p.188.

Fiaboe, K.K.M. and A.L. Roda. 2012. Predicting the potential worldwide distribution of the Red Palm Weevil Rhynchophorus ferrugineus (Olivier) (coleoptera:curculionidae) using ecological niche modeling. Florida Entomologist, 95: 659-673. https://doi.org/10.1653/024.095.0317

Gindin G.; S. Levski, I. Glazer and V. Soroker. 2006. Evaluation of the entomopathogenic fungi Metarhizium anisopliae and Beauveria bassiana against the red palm weevil Rhynchophorus ferrugineus. Phytoparasitica, 34:370-379. https://doi.org/10.1007/bf02981024

Griffith, R. 1968. The relationship between the red ring nematode and the palm weevil. Journal of the Agricultural Society of Trinidad and Tobago, 68: 342356.

Griffith, R. 1987. Red ring disease of coconut palm. Plant Disease 71: 193-196.

Hagley, E. 1963. The role of the palm weevil as a vector of red ring disease of coconuts. Journal of Economic Entomology, 56: 375-380.

Hallett, R.H., A.C. Oehlschlager, and J.H. Borden. 1999. Pheromone trapping protocols for the Asian palm weevil, Rhynchophorus ferrugineus (Coleoptera: Curculionidae). International Journal of Pest Management, 45: 231-237. https://doi.org/10.1080/096708799227842
Lo Verde, G., L.Torta, V. Mondello, C. G. Caldarella, S. Burruano, V. Caleca. 2015. Pathogenicity bioassays of isolates of Beauveria bassiana on Rhynchophorus ferrugineus. Pest Management Science, 71: 323-328. https://doi.org/10.1002/ps.3852

Lohr, B. 2015. Rhynchophorus ferrugineus, a very dangerous pest of palms worldwide. I Simpósio de Pragas Quarentenárias na Amazônia Brasileira. Memorias. Embrapa Roraima. p 21-23.

Moura, J., E. Vilela, R. Sgrillo, M. Aguilar and M. Resende. 1989. A behavioral olfactory study of Rhynchophorus palmarum in the field. Anais da Sociedade Entomológica do Brasil, 18: 267-274.

Moura, J.I.L, D. Mauriau and J.H.C. Delabie. 1993. Eficiência de Paratheresia menezesi Townsend (Díptera: Tachidae) no controle biológico natural de Rhynchophorus palmarum (L.) (Coleóptera: Curculionidae). Oléagineux 48: 219-23

Moura, J.I., R. Toma, R.B. Sgrillo and J.H.C. Delabie. 2006. Eficiência do parasitismo natural por Billaea rhynchophorae (Blanchard) (Diptera: Tachinidae) para o controle de Rhynchophorus palmarum (L.) (Coleoptera: Curculionidae). Neotropical Entomology, 35: 273-274.

https://doi.org/10.1590/s1519-566x2006000200019

Murphy, S.T., B-R. Briscoe. 1999. The red palm weevil as an alien invasive: biology and prospects for biological control as a component of IPM. Biocontrol News and Information, 20: 35-45

Porcelli, F. and D. Cornara. 2013. Mezzi e metodi di controllo integrato del Punteruolo Rosso delle Palme. Atti Accademia Nazionale Italiana di Entomologia, LXI: 233-238.

Porcelli F., I. Al-Jboory and H.Y.A. Raheem. 2012. Key Factors in red palm weevil biology (Rhynchophorus ferrugineus) (Curculionoidea). Proceeding of XXVIII International Horticultural Congress on Science and Horticulture for People (IHC2010): International Symposium on the Challenge for a Sustainable Production, Protection and Consumption of Mediterranean Fruits and Nuts. A. D'Onghia, I. Batlle, T. Caruso, L. Corelli Grappadelli, O. Callesen and J. Bonany (eds). ISHS Acta Horticulturae, 940: 591-596. https://doi.org/10.17660/actahortic.2012.940.83

Ramachandran, C.P. 1998. The red palm weevil Rhynchophorus ferrugineus: a review and future strategies. Indian Coconut Journal, 29: 104-106.

Rochat, D., A. Gonzalez, D. Marian, A. Villanueva and P. Sagatti. 1991a. Evidence for male-produced aggregation pheromone in Rhynchophorus palmarum. Journal of Chemical Ecology, 17: 1221-1230 https://doi.org/10.1007/bf01402945

Rochat, D., C. Malosse, M. Lettere, P.H. Ducrot, P. Zagatti, M. Renou and C. Descoins. 1991b. Maleproduced aggregation pheromone of Rhynchophorus palmarum: collection, identification, electrophysiological activity, and laboratory bioassay. Journal of Chemical Ecology, 17: 2127-2141 https://doi.org/10.1007/BF00987996

Rochat, D., O. Dembillo, J.A. Jaques, P. Suma, A. Pergola, R. Hamidi, D. Kontodimas and V. Soroker. 
2017. Rhynchophorus ferrugineus: Taxonomy, Distribution, Biology and Life Cycle. Pages 69-104. In: Handbook of Major Palm Pests, Chapter: 4, eds: Colazza, S. and Soroker, V. Wiley Blackwell, 2017

Roda, A., M. Kairo, T. Damian, F. Franken, K. Heidweiller, C. Johanns and R. Mankin. 2011. Red palm weevil, (Rhynchophorus ferrugineus), an invasive pest recently found in the Caribbean that threatens the region. OEPP/EPPO Bulletin, 41: 116121. https://doi.org/10.1111/j.1365-2338.2011.02446.x

Rugman-Jones, P.F., C.D. Hoddle, M.S. Hoddle and R. Stouthamer. 2013. The lesser of two weevils: Molecular genetics of pest palm weevil populations confirm Rhynchophorus vulneratus (Panzer 1798) as a valid species distinct from $R$. ferrugineus (Olivier 1790), and reveal the global extent of both. PLoSONE 8: e78379. https://doi.org/10.1371/journal.pone.0078379

Sánchez, P. and H. Cerda. 1993. The complex Rhynchophorus palmarum/ Bursaphelenchus cocophilus in palms. Boletín de Entomología Venezolana, 8: 1-18.

Santana, D.L.Q. and M.F. de Lima. 1992. Patogenicidade do fungo Beauveria bassiana (Balz.) Vuill. a adultos de Rhynchophorus palmarum (L.). In: SIMPÓSIO DE
CONTROLE BIOLÓGICO, 3., Águas de Lindóia, SP. Anais... Jaguariúna: Embrapa-CNPDA, 1992. p. 242

Schuiling, M. and J. van Dinther. 1981. Red ring disease in the Paricatuba oil palm estate, Brazil. Zeitschrift für Angewandte Entomologie, 91: 154-169.

Scrascia M., C. Pazzani, F. Valentini, M. Oliva, V. Russo, P. D'Addabbo and F. Porcelli. 2016. Identification of pigmented Serratia marcescens symbiotically associated with Rhynchophorus ferrugineus Olivier (Coleoptera: Curculionidae). MicrobiologyOpen, 5: 883-890. https://doi.org/10.1002/mbo3.377

Soroker, V., D. Blumberg, A. Haberman, M. Hamburguer-Rishard, S. Reneh and S. Talebaev. 2005. Current status of red palm weevil infestation in date palm plantations in Israel. Phytoparasitica, 33: 97 106. https://doi.org/10.1007/bf02980931

Vacas, S., O. Melita, A. Michaelakis, P. Milonas, R. Minuz, P. Riolo and V. Soroker. 2017. Lures for red palm weevil trapping systems: aggregation pheromone and synthetic kairomone. Pest Management Science, 73: 223-231. https://doi.org/10.1002/ps.4289

Vidyasagar, P.S.P.V., M. Hagi, R.A. Abozuhairah, O.E. Al-Mohanna and A.A. Al-Saihati. 2000. Impact of mass pheromone trapping on red palm weevil adult population and infestation level in date palm gardens of Saudi Arabia. Planter, 76: 347-355. 